\title{
The toxic dinoflagellate Alexandrium minutum affects oyster gamete health and fertilization potential
}

\author{
Castrec Justine ${ }^{3,}{ }^{*}$, Fabioux Caroline ${ }^{3}$, Le Goïc Nelly ${ }^{2}$, Boulais Myrina ${ }^{1}$, Soudant Philippe ${ }^{2}$, \\ Hégaret Helene ${ }^{2}$
}

\begin{abstract}
1 LEMAR UMR 6539 CNRS/UBO/IRD//fremer, IUEM, rue Dumont d'Urville, 29280, Plouzané, France
2 LEMAR UMR 6539 CNRS/UBO/IRD//fremer, IUEM, rue Dumont d'Urville, 29280, Plouzané, France

${ }^{3}$ LEMAR UMR 6539 CNRS/UBO/IRD//fremer, IUEM, rue Dumont d'Urville, 29280, Plouzané, France

* Corresponding author : Justine Castrec, email address : Justine.Castrec@gmail.com
\end{abstract}

\begin{abstract}
:
Dinoflagellates from the globally distributed genus Alexandrium are known to produce both paralytic shellfish toxins (PST) and uncharacterized bioactive extracellular compounds (BEC) with allelopathic, ichthyotoxic, hemolytic and cytotoxic activities. In France, blooms of Alexandrium minutum appear generally during the spawning period of most bivalves. These blooms could therefore alter gametes and/or larval development of bivalves, causing severe issues for ecologically and economically important species, such as the Pacific oyster Crassostrea (=Magallana) gigas. The aim of this work was to test the effects of three strains of A. minutum producing either only PST, only BEC, or both PST and BEC upon oyster gametes, and potential consequences on fertilization success. Oocytes and spermatozoa were exposed in vitro for 2 hours to a range of environmentally realistic A. minutum concentrations (10 to 2.5 $\times 104$ cells $\mathrm{mL}-1$ ). Following exposure, gamete viability and reactive oxygen species (ROS) production were assessed by flow cytometry, spermatozoa motility and fertilization capacities of both spermatozoa and oocytes were analysed by microscopy. Viability and fertilization capacity of spermatozoa and oocytes were drastically reduced following exposure to $2.5 \times 104$ cells $\mathrm{mL}-1$ of $\mathrm{A}$. minutum. The BEC-producing strain was the most potent strain decreasing spermatozoa motility, increasing ROS production of oocytes, and decreasing fertilization, from the concentration of $2.5 \times 103$ cells $\mathrm{mL}-1$. This study highlights the significant cellular toxicity of the BEC produced by A. minutum on oyster gametes. Physical contact between gametes and motile thecate $A$. minutum cells may also contribute to alter oyster gamete integrity. These results suggest that oyster gametes exposure to A. minutum blooms could affect oyster fertility and reproduction success.
\end{abstract}

\section{Highlights}

Oyster spermatozoa and oocytes were exposed in vitro to Alexandrium minutum strains. Viability and fertilization capacity of gametes were drastically reduced. The toxicity of Alexandrium minutum upon oyster gametes is strain-specific. A non-PST-producing strain increased reactive oxygen species production in oocytes. This strain also decreased spermatozoa motility and gamete fertilization. 
Keywords: Algal blooms, Algal toxins, Fertilization, Paralytic Shellfish Toxins (PST), Bioactive Extracellular Compounds (BEC), Spermatozoa, Oocyte, Flow cytometry, Crassostrea (=Magallana) gigas, Bivalves. 


\section{Introduction}

Fertilization is essential for reproduction and population sustainability (Marshall et al., 2002). Most marine bivalve molluscs are broadcast spawners depending on external fertilization. Seawater quality is a main factor affecting fertilization and larval development successes in these organisms (Havenhand et al., 2008). In particular, contaminants could negatively affect their reproduction as demonstrated in oysters exposed to anthropogenic pollutants (Akcha et al., 2012; Fitzpatrick et al., 2008; Mai et al., 2013; Vignier et al., 2017, 2015). Experimental studies suggest that harmful algal blooms (HAB), often caused by dinoflagellates, can affect marine bivalve reproduction by altering gamete quality and larval development, growth, and survival (Banno et al., 2018; Basti et al., 2013, 2011; Binzer et al., 2018; Bricelj and MacQuarrie, 2007; Castrec et al., 2020, 2019; De Rijcke et al., 2015; Gaillard et al., 2020; Rolton et al., 2018, 2015, 2014; Tang and Gobler, 2012). In coastal areas, $\mathrm{HAB}$ are a recurring phenomenon that can co-occur with the reproduction of free spawning marine organisms (Gaillard et al., 2020).

In France, blooms of Alexandrium minutum usually occur from April to November (Pouvreau et al., 2016) overlapping with Pacific oyster breeding and spawning periods (Fig. S1). An understanding of the effects of A. minutum cells and its toxic compounds on gametes and early life stages of Crassostrea (=Magallana) gigas (Bayne et al., 2017) is therefore critically important, considering the economic and ecological importance of this bivalve species. The known consequences of Alexandrium blooms are both ecological (e.g., alteration of marine trophic structure, large-scale mortality of fish and shellfish) and economic (e.g., impairment of tourism and recreational activities, fishery closure and sell prohibition of shellfish) (Anderson et al., 2012b).

HAB species from the genus Alexandrium are known to produce paralytic shellfish toxins (PST) that can cause human poisoning through shellfish-mediated intoxications (Bricelj and 
Shumway, 1998) and/or poorly uncharacterized bioactive compounds exerting allelopathic, hemolytic, ichthyotoxic or cytotoxic activities (Arzul et al., 1999; Bianchi et al., 2019; Castrec et al., 2020, 2018; Ford et al., 2008; Lelong et al., 2011; Long et al., 2018a, 2018b; Mardones et al., 2015). These bioactive compounds were proposed to be implicated in the toxicity of Alexandrium upon early embryo development of several marine bivalves, such as Mytilus edulis (De Rijcke et al., 2016), C. gigas (Castrec et al., 2020; Mu and Li, 2013), and Pinctada fucata martensii (Basti et al., 2015), independently of the well-known toxins PST, gonyautoxins, and spirolids. However, no clear demonstration of the respective effects of the different toxic compounds has been provided. In addition to the well-known and characterized PST, recent studies demonstrated the toxicity of unidentified bioactive extracellular compounds (BEC) produced by A. minutum on other microalgae species (Lelong et al., 2011; Long et al., 2018a, 2018b) and their deleterious effects upon the behavior of the scallop Pecten maximus (Borcier et al., 2017) and physiology of the oyster C. gigas (Castrec et al., 2018). These BEC were supposed to affect oyster oocytes exposed in vitro (Le Goïc et al., 2014) as well as spermatozoa derived from exposed oysters (Castrec et al., 2019; Haberkorn et al., 2010). To our knowledge, the respective involvement of PST and BEC in A. minutum toxicity toward $C$. gigas gametes is not yet clearly established.

In the present study, we investigated the toxicity of $A$. minutum on $C$. gigas gametes by measuring their cellular characteristics by flow cytometry and the fertilization success of spermatozoa or oocytes by microscopy. Spermatozoa motility and swimming velocity were analysed by microscopy and image analysis. To determine the respective toxicity of BEC and PST, three A. minutum strains were tested, either producing only PST, only BEC, or both PST and BEC.

\section{Materials and methods}

\subsection{Algal strains}



supplemented with L1-Si medium (Guillard and Hargraves, 1993) and maintained at $17 \pm 1$ ${ }^{\circ} \mathrm{C}$, under a continuous light intensity of $100-110 \mu \mathrm{mol}$ photons $\mathrm{m}^{-2} \mathrm{~s}^{-1}$. The A. minutum strains were (i) the PST+BEC strain (strain AM89BM, isolated from a bloom in the Bay of

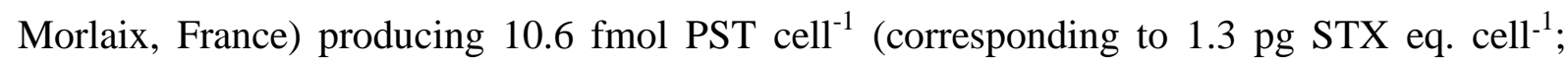
Fabioux et al., 2015); (ii) the PST strain (strain Da1257, isolated from a bloom in the Bay of Daoulas, France) producing 0.63 fmol PST cell ${ }^{-1}$ (corresponding to 0.053 pg STX eq. cell ${ }^{1}$; Pousse et al., 2018); (iii) the BEC strain (strain CCMI1002, isolated from Irish waters), for which no PST were detected (Borcier et al., 2017).

According to the bioassay developed by Long et al. (2018a), the BEC strain appears four times more cytotoxic than the PST+BEC strain, whereas the PST strain has a negligible cytotoxic potency. Cultures were not axenic, grown without antibiotics, and harvested in exponential growth phase for the experiments. Algal concentrations (cells $\mathrm{mL}^{-1}$ ) were determined by counts using a FACScalibur (BD Sciences, San Jose, CA, USA) flow cytometer equipped with a blue laser (excitation $488 \mathrm{~nm}$ ) according to Marie et al. (1999). For gamete cellular responses and fertilization experiments, cultures were re-suspended in filtered seawater $24 \mathrm{~h}$ prior to the exposures to reach cell concentrations of $2 \times 10^{1}, 2 \times 10^{2}, 5 \times 10^{3}$, and $5 \times 10^{4}$ cells $\mathrm{mL}^{-1}$.

\subsection{Oysters}

For the experiment assessing cellular responses of gametes exposed to A. minutum, adult Pacific oysters ( $\mathrm{n}=5$ females and $\mathrm{n}=4$ males) $C$. gigas were collected from Daoulas estuary in the Bay of Brest (North Brittany, France). For the fertilization experiment, adult oysters (n $=3$ females and $n=3$ males) originated from a cohort produced in 2017 according to Petton et al. (2015) and were deployed as early-juveniles (i.e. spat) in the bay of Brest. Gravid oysters were collected during the natural reproduction period (June and July 2018). 


\subsection{Collection of gametes}

109 Oyster gender determination and gamete quality check, i.e. round shape of oocytes and 110 spermatozoa motility, were performed by examination of $2 \mu \mathrm{L}$ gonad samples under a light

111 microscope (Leica MZ 125, ×10 objective) before each experiment. Oocytes and spermatozoa

112 were then collected by stripping gonads individually (Boulais et al., 2015a, b). Briefly, 113 gametes were collected in $0.2-\mu \mathrm{m}$ filtered seawater (FSW; $\mathrm{pH} 8.12$, salinity $34.7,21{ }^{\circ} \mathrm{C}$ ) and 114 sieved through $100-\mu \mathrm{m}$ mesh to eliminate cellular debris. Cell concentrations were 115 determined individually by flow cytometry (FCM) (duplicate, EasyCyte Plus cytometer, 116 Guava Millipore Luminex) according to Le Goïc et al. (2014, 2013). The concentration of 117 oocyte suspensions were adjusted to $1 \times 10^{5}$ cells $\mathrm{mL}^{-1}$ with FSW. Spermatozoa suspensions 118 were diluted to $1 \times 10^{8}$ cells $\mathrm{mL}^{-1}$ with $\mathrm{FSW}$ for movement measurements, and to $2 \times 10^{6}$ 119 cells $\mathrm{mL}^{-1}$ for gamete cellular responses and fertilization experiments.

2.4 Gamete cellular responses experiment: spermatozoa movement and gamete FCM analyses

For each oyster, $2.5 \mathrm{~mL}$ of gamete suspension (see section 2.3) were exposed for 2 hours to $2.5 \mathrm{~mL}$ of the A. minutum suspensions ( 3 A. minutum strains $\times 4$ concentrations) or to $2.5 \mathrm{~mL}$ of FSW (control treatment) in $10 \mathrm{~mL}$ glass vials for FCM analyses. For spermatozoa motility analyses, $0.5 \mathrm{~mL}$ subsample of spermatozoa suspension from each male was transferred in 2 $\mathrm{mL}$ glass vials containing $0.5 \mathrm{~mL}$ of the A. minutum suspensions or $0.5 \mathrm{~mL}$ of FSW (control treatment). After 2 hours of exposure, spermatozoa were sampled for motility measurements.

128 Final A. minutum concentrations were $10,10^{2}, 2.5 \times 10^{3}$, and $2.5 \times 10^{4}$ cells $\mathrm{mL}^{-1}$. These 129 concentrations were chosen to reflect the range of algal densities observed during natural 130 blooms (Chapelle et al., 2015). In France, the alert threshold triggering weekly concentration 131 monitoring for A. minutum blooms is 10 cells $\mathrm{mL}^{-1}$ (Guallar et al., 2017). 
FCM measurements for spermatozoa and oocytes (i.e. relative cell size and complexity,

133 viability (using Sybr-14 and propidium iodide, final concentration $1 \mu \mathrm{M}$ and $10 \mu \mathrm{g} \mathrm{L}^{-1}$,

134 respectively) and reactive oxygen species production (using DCFH-DA, final concentration

$13510 \mu \mathrm{M})$ ), were performed using an EasyCyte Plus cytometer (Guava Millipore Luminex)

136 equipped with standard optics and a $488 \mathrm{~nm}$ argon laser according to Le Goïc et al. (2013,

137 2014).

138 Spermatozoa movement was analyzed under phase contrast microscope coupled to a video 139 camera (Qicam Fast 1394) according to (Boulais et al., 2018). Briefly, each spermatozoa 140 suspension was diluted 2 times in FSW containing pluronic acid (final concentration of $1 \mathrm{~g} \mathrm{~L}^{-}$

$141^{1}$ ) to avoid spermatozoa sticking to the cell surface. Then, $12 \mu \mathrm{L}$ of diluted spermatozoa 142 suspension was immediately transferred to a Fast-Read® cell 102 (Fisher Scientific) and the 143 percentage of motile spermatozoa and their velocity (VAP: Velocity of the Average Path) 144 were assessed on a minimum of 30 spermatozoa for each sample, using the ImageJ software 145 and a CASA plug-in calibrated to Pacific oyster (Boulais et al., 2015b).

\section{$2.5 \quad$ Fertilization experiment}

147 For each oyster, $2.5 \mathrm{~mL}$ of gamete suspension (oocytes or spermatozoa, see section 2.3)

148 were exposed for 2 hours to $2.5 \mathrm{~mL}$ of the A. minutum culture ( 3 A. minutum strains $\times 4$ 149 concentrations) or to $2.5 \mathrm{~mL}$ of FSW (control treatment) in $10 \mathrm{~mL}$ glass vials. Fertilization of

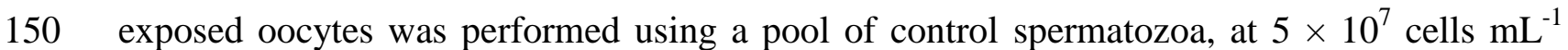
151 prepared from the initial spermatozoa suspensions of 3 males (see section 2.3). Fertilization of 152 exposed spermatozoa was performed using a pool of control oocytes, at $5 \times 10^{4}$ cells $\mathrm{mL}^{-1}$, 153 prepared from initial oocyte suspensions of 3 female oysters (see section 2.3). After the 154 exposure to A. minutum, exposed oocytes $\left(5 \times 10^{3}\right.$ oocytes $)$ were transferred to 24 -well 155 microplates $\left(\mathrm{NUNC}^{\odot}\right)$ filled with $2 \mathrm{~mL}$ of FSW and $10 \mu \mathrm{L}$ of the non-exposed spermatozoa 156 pool (100:1 spermatozoa:oocyte ratio). Similarly, exposed spermatozoa $\left(5 \times 10^{5}\right.$ spermatozoa $)$ 
157

158

were transferred to 24 -well microplates $\left(\mathrm{NUNC}^{\odot}\right)$ filled with $1.4 \mathrm{~mL}$ of FSW and $100 \mu \mathrm{L}$ of the non-exposed oocytes pool (100:1 spermatozoa:oocyte ratio). After 2 hours of contact between spermatozoa and oocytes, samples were fixed with a formaldehyde-seawater solution (1\% final) to estimate the fertilization yield using a light microscope (Leica DM-IRB). Numbers of fertilized (2-cell or 4-cell embryos) and unfertilized (absence of segmentation) oocytes were counted, on at least 100 oocytes per well. Fertilization yield was defined as number of fertilized oocytes $\times 100 /$ number of unfertilized and fertilized oocytes. Each oocytes/spermatozoa fertilization assay was performed in triplicate, the mean of the triplicate fertilizations was used in statistical tests.

\subsection{Statistical analyses}

Statistical analyses and graphical representations were performed using $\mathrm{R}$ software ( $\mathrm{R}$ Core Team, 2012). Differences were considered significant when $p<0.05$. All values are expressed as mean \pm standard error (SE). Normality and homogeneity of variance were verified by the Shapiro-Wilk and Levene methods, respectively. Cellular characteristics measured by flow cytometry and fertilization yields were compared between the 13 treatments ( 3 A. minutum strains $\times 4$ concentrations, and the control) for oocytes and spermatozoa using repeated measures ANOVA ('nlme' package), with 'treatment' as a fixed factor and 'oyster' as a random factor. For all models, we checked the assumption of homogeneity of variance and normality of residuals graphically using normal quantilequantile plots and scale-location plots of $\operatorname{sqrt}(\mid$ residuals $\mid)$. The viability variable was transformed as arcsin(squareroot) before statistical analysis to pass normality, but were presented as non-transformed data in figures. A repeated measures ANOVA was used to test the effect of A. minutum exposure on spermatozoa motility and velocity, accounting for oyster as a random factor. If the effect of treatment was significant, post-hoc analyses were performed using emmeans function with Tukey's correction. 


\subsection{Gamete cellular responses}

184 The viability of spermatozoa $\left(\mathrm{F}=23.47, p<10^{-12}\right)$ and oocytes $\left(\mathrm{F}=12.76, p<10^{-10}\right)$ were

185 only affected at the highest $A$. minutum concentration tested, i.e. $2.5 \times 10^{4}$ cells $\mathrm{mL}^{-1}$ (Fig. $1 \mathrm{~A}$, B).
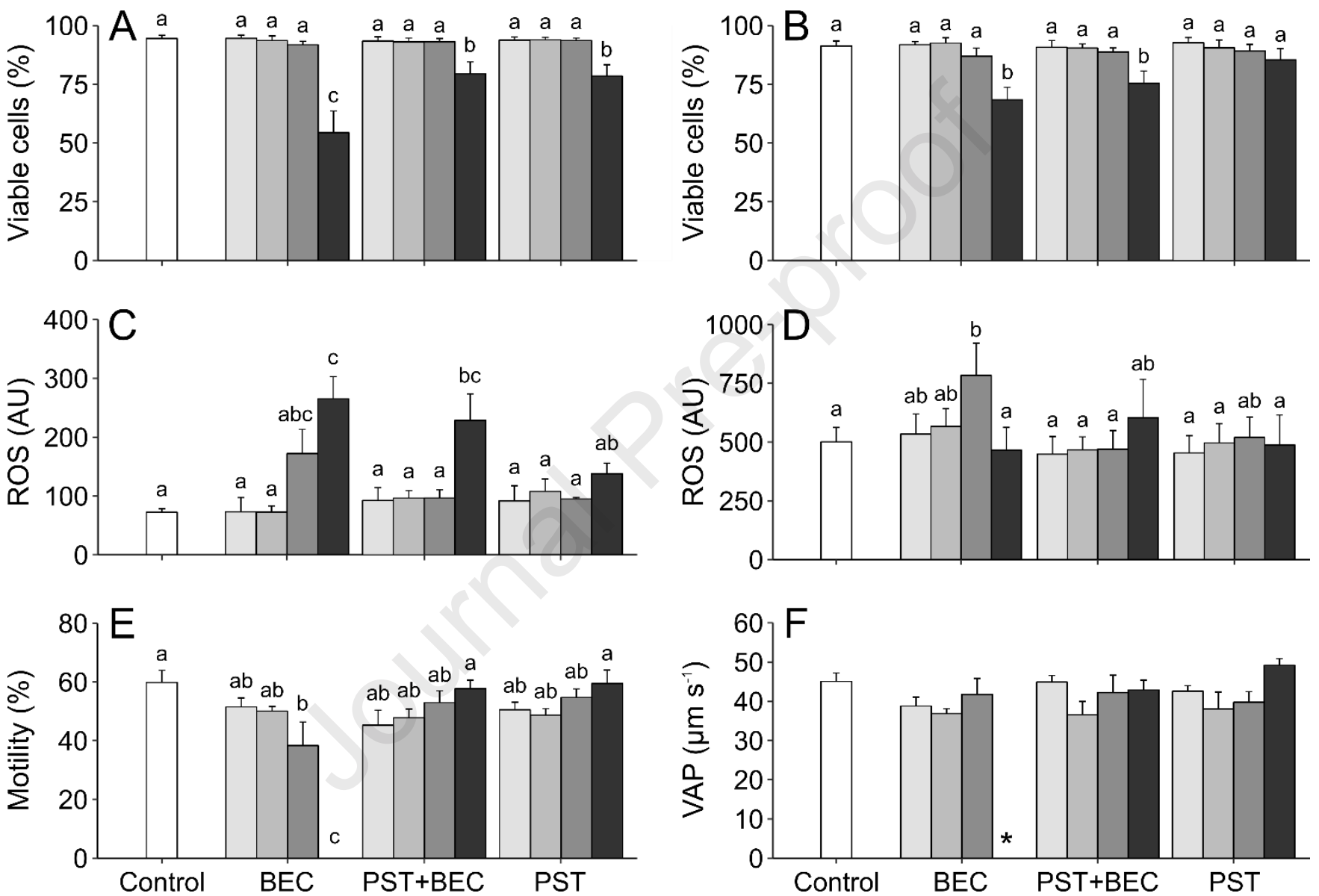

Fig. 1. Effects of three A. minutum strains producing BEC, PST+BEC, or PST, on cellular features of $C$. gigas gametes after a 2-hour exposure of spermatozoa ( $\mathrm{n}=4$ males) or oocytes ( $\mathrm{n}=5$ females) to $10(\square), 10^{2}(\square), 2.5 \times 10^{3}(\square)$, and $2.5 \times 10^{4}(\square)$ cells $\mathrm{mL}^{-1}$ of A. minutum or to seawater $(\square)$ (control).

190 Percentage of viable spermatozoa (A) and oocytes (B), reactive oxygen species (ROS) production of spermatozoa (C) and oocytes (D), spermatozoa motility (E) and velocity of the average path (VAP) (F). *: VAP of spermatozoa exposed to $2.5 \times 10^{4}$ cells $\mathrm{mL}^{-1}$ of the BEC strain was 0 , as movement was totally inhibited. AU: arbitrary unit. Error bars denote \pm standard error. Letters denote significant groupings $(p<0.05)$.

At this concentration, the percentages of viable spermatozoa exposed to the three $A$. minutum strains were lower than control spermatozoa $(94.4 \pm 1.4 \%)$, the BEC strain having 
the strongest effect $(-38 \%)$ on spermatozoa viability $(54.3 \pm 9.3 \%)$ compared to the PST+BEC

198 (79.4 $\pm 5.1 \%$, i.e. $-14 \%)$ and PST strains $(78.5 \pm 4.8 \%$, i.e. $-15 \%)$ (Fig. 1A). The viability of oocytes exposed to $2.5 \times 10^{4}$ cells $\mathrm{mL}^{-1}$ of the BEC strain $(68.4 \pm 5.3 \%)$ or of the PST+BEC strain $(75.4 \pm 5.2 \%)$ were lower $(-21 \%$ and $-14 \%$, respectively) than control oocytes $(91.3 \pm$ 2.1\%) (Fig. 1B). The PST strain did not significantly affect oocyte viability compared to control (Fig. 1B).

The production of reactive oxygen species (ROS) of spermatozoa $\left(\mathrm{F}=8.29, p<10^{-6}\right)$ and oocytes $\left(\mathrm{F}=2.70, p<10^{-2}\right)$ were modified by exposure to $A$. minutum. The ROS production of spermatozoa exposed to $2.5 \times 10^{4}$ cells $\mathrm{mL}^{-1}$ of the BEC strain $(265.5 \pm 37.5 \mathrm{AU})$ or the PST+BEC strain $(228.6 \pm 45.0$ AU) were higher $(+140 \%$ and $+113 \%$, respectively) than control spermatozoa (72.4 \pm 6.0 AU) (Fig. 1C). The ROS production of oocytes exposed to $2.5 \times 10^{3}$ cells $\mathrm{mL}^{-1}$ of the BEC strain $(783.9 \pm 136.8 \mathrm{AU})$ was higher $(+56 \%)$ than control oocytes $(500.8 \pm 61.4$ AU) (Fig. 1D). In the other conditions, ROS production of exposed gametes were similar to control (Fig. 1C, D).

Spermatozoa motility was significantly affected by $A$. minutum exposure $(\mathrm{F}=19.66$, $p<10^{-11}$ ). Exposure to $2.5 \times 10^{4}$ cells $\mathrm{mL}^{-1}$ of the BEC strain totally inhibited spermatozoa 213 movement (Fig. 1E). The percentage of motile spermatozoa in spermatozoa exposed to $2.5 \times$ $21410^{3}$ cells $\mathrm{mL}^{-1}$ of the BEC strain $(38.3 \pm 8.0 \%)$ was lower $(-36 \%)$ than in control spermatozoa $215(59.8 \pm 4.1 \%)$ (Fig. 1E). The motility of spermatozoa in the other conditions were similar to 216 control (Fig. 1E). The velocity of motile spermatozoa (VAP: Velocity of the Average Path) 217 were not significantly affected by A. minutum exposure (Fig. 1F), except for the VAP of 218 spermatozoa exposed to $2.5 \times 10^{4}$ cells $\mathrm{mL}^{-1}$ of the BEC strain, which could not be measured since spermatozoa movement was totally inhibited (Fig. 1E). 
Pre-exposure of oocytes or spermatozoa to A. minutum, prior to gamete contact for

222 fertilization test, significantly affected fertilization yields (spermatozoa: $\mathrm{F}=10.78, p<10^{-6}$;

223 oocytes: $\mathrm{F}=29.60, p<10^{-10}$ ). The fertilization yields obtained using spermatozoa exposed to

224 the BEC strain at the two highest concentrations tested $\left(2.5 \times 10^{4}\right.$ and $2.5 \times 10^{3}$ cells mL $\left.^{-1}\right)$

225 were significantly lower $(1.4 \pm 1.4 \%$ and $24.5 \pm 18.2 \%$, i.e. -98 and $-73 \%$, respectively) than

226 fertilization yield obtained using control spermatozoa $(92.3 \pm 0.5 \%)$. Similarly, spermatozoa

227 exposure to the highest concentration $\left(2.5 \times 10^{4}\right.$ cells $\left.\mathrm{mL}^{-1}\right)$ of the PST+BEC strain or the

228 PST strain significantly decreased fertilization yields $(12.6 \pm 10.8 \%$ and $21.6 \pm 14.4 \%$, i.e. -

$22986 \%$ and $-77 \%$, respectively) compared to control (Fig. 2A). Exposure of oocytes also

230 induced lower fertilization yields compared to control oocytes $(90.9 \pm 2.7 \%)$ when exposed to

231 the two highest concentrations tested $\left(2.5 \times 10^{4}\right.$ and $2.5 \times 10^{3}$ cells $\left.\mathrm{mL}^{-1}\right)$ of the BEC strain $232\left(0.1 \pm 0.1 \%\right.$ and $49.0 \pm 13.5 \%$, i.e. -99 and $-46 \%$, respectively), and to $2.5 \times 10^{4}$ cells $\mathrm{mL}^{-1}$ of 233 the PST+BEC strain $(32.3 \pm 3.9 \%$, i.e. $-64 \%)$ or the PST strain $(62.3 \pm 1.3 \%$, i.e. $-31 \%)$ (Fig.
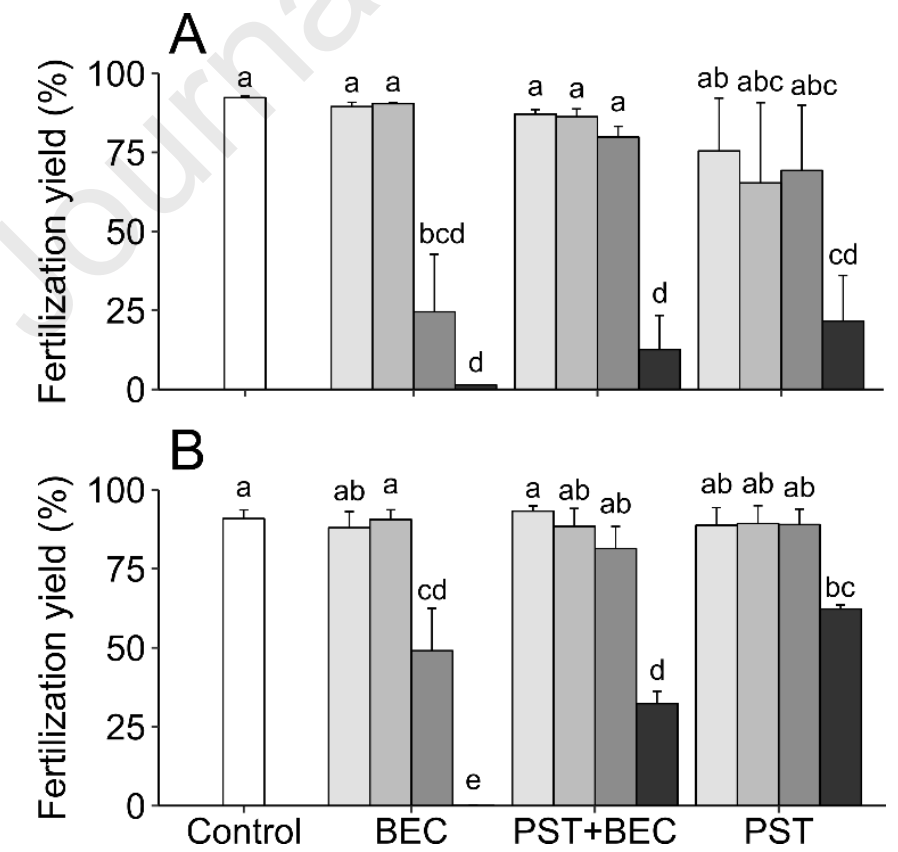

234 2B). The other concentrations of the A. minutum strains induced similar responses than 235 control condition. 
236 Fig. $\square$. Effets of three A. minutum strans producing BEC, PST+BEC, or PST, on C. gigas 237 fertilization yierd after a 2-hour exposure of spermatozoa ( $\mathrm{n}=3$ males $)$ or oocytes $(\mathrm{n}=3$ females $)$ to 23810()$, 10^{2}(\mathrm{)}), 2.5 \times 10^{3}$ ( ), and $2.5 \times 10^{4}$ ( ) cells $\mathrm{mL}^{-1}$ of A. minutum (Pre-fertilization experiment) 239 or to seawater ( ) (control). Fertilization yields of exposed spermatozoa (A) and exposed oocytes (B).

240 Error bars denote \pm standard error. Letters denote significant groupings $(p<0.05)$. 


\section{Discussion}

The present study evidences that concentrations of $2.5 \times 10^{3}$ cells $\mathrm{mL}^{-1}$ of Alexandrium minutum induced sublethal defects on oyster gametes after only two hours of in vitro

244 exposure. The extent of the effects depended on the A. minutum strain, the toxic compound 245 they produced and exposure concentration. Cellular damages on spermatozoa or oocytes were 246 associated to significant decreases in fertilization yields, the ultimate phenotype translating 247 the quality of gametes. The highest concentrations tested (up to $2.5 \times 10^{4}$ cells $\mathrm{mL}^{-1}$ ) are in 248 the range of values observed during severe A. minutum blooms in France, Spain, Egypt, and 249 South Africa (Chapelle et al., 2015; Garcés et al., 2004; Labib and Halim, 1995; Pitcher et al., 250 2007) and demonstrate the potentiality of ecological consequences of A. minutum blooms for 251 wild and cultivated bivalve populations.

252 Sublethal cellular damages and consequences on fertilization were most severe with the 253 BEC-producing A. minutum strain, illustrating the high toxicity of bioactive extracellular 254 compounds to oyster gametes. This strain significantly decreased fertilization when 255 spermatozoa $(-73 \%)$ or oocytes $(-49 \%)$ were exposed at $2.5 \times 10^{3}$ cells $\mathrm{mL}^{-1}$ and almost 256 totally inhibited it for gamete exposure at $2.5 \times 10^{4}$ cells $\mathrm{mL}^{-1}$. This strain was also 257 characterized as the most allelopathic, i.e. cytotoxic, for diatoms (Long et al., 2018a) and 258 oyster embryos (Castrec et al., 2020).

259 In addition to a high cellular mortality rate $(45.7 \%)$, inhibition of spermatozoa motility 260 likely explain the drastic decrease in fertilization yield following spermatozoa exposure to the 261 BEC strain since concentration of motile spermatozoa is a pivotal factor for successful 262 fertilization in free-spawning marine invertebrates (Nice, 2005; Styan, 1998). The motility 263 was significantly reduced after an exposure to $2.5 \times 10^{3} \mathrm{~A}$. minutum cells $\mathrm{mL}^{-1}$ and totally at $2642.5 \times 10^{4}$ cells $\mathrm{mL}^{-1}$. Alteration of spermatozoa movement could result from membrane 265 alteration or sub-cellular cytotoxic effects. Long et al. (2018b) highlighted the deleterious 
effects of extracellular bioactive compounds produced by the BEC strain of A. minutum on

membranes of the diatom Chaetoceros muelleri, with modifications of the proportion of lipid

classes, pigments, and of the photosynthetic chain suggesting an alteration of membrane

integrity, associated with an increase of internal ROS production of the diatom. In human,

oxidative stress is largely implicated in reproductive physiopathology. An excessive ROS production was demonstrated to be deleterious for sperm membrane integrity, motility, and fertility (Agarwal et al., 2003), by inducing peroxidative damage to the plasma membrane and DNA fragmentation (Sanocka and Kurpisz, 2004). Consequently, higher ROS production in spermatozoa exposed to $2.5 \times 10^{4}$ cells $\mathrm{mL}^{-1}$ of the BEC strain or the PST+BEC strain could be another element to explain spermatozoa reduced motility and viability. The increase in ROS production in oocytes exposed to $2.5 \times 10^{3}$ cells $\mathrm{mL}^{-1}$ of the BEC strain could be associated with BEC, as ROS generation in cells can be triggered by exposure to xenobiotic or toxins (Manduzio et al., 2005). As proposed by Le Goïc et al. (2014), ROS generation in oocytes exposed to A. minutum could lead to cellular damages and subsequently alter fertilization processes. High concentrations of intracellular ROS in human oocytes are responsible for detrimental effects such as disruption of $\mathrm{Ca}^{2+}$ homeostasis (Martín-Romero et 282 al., 2008; Takahashi et al., 2003), impaired fertilization, and altered cleavage (Bedaiwy et al., 2002; Hu et al., 2001).

284 Bioactive extracellular compounds produced by different dinoflagellate species generally appear highly toxic for gametes (this study) and early developmental stages of bivalves, not protected by a shell (Banno et al., 2018; Basti et al., 2015; Castrec et al., 2020; Rolton et al., 287 2015). It is urgent to consider these uncharacterized bioactive compounds in studies assessing the effects of $\mathrm{HAB}$ on marine species, to characterize them, and to decipher the mechanisms underlying their toxicity. 
Exposure of spermatozoa or oocytes to the PST-producing A. minutum strain at $2.5 \times 10^{4}$ 291 cells $\mathrm{mL}^{-1}$ also altered fertilization and induced mortality in spermatozoa. Although PST is mainly intracellular in dinoflagellates, low levels of extracellular PST have been measured in the culture media of some Alexandrium spp. isolates (Lefebvre et al., 2008). Extracellular PST might have been present in the PST strain culture media and could be involved in the toxic effects observed. Saxitoxin, binding to $\mathrm{Na}^{+}$and $\mathrm{Ca}^{2+}$ channels (Llewellyn, 2006), likely modifies fluxes of these ions in cells. Saxitoxin could therefore alter cellular processes involving $\mathrm{Ca}^{2+}$, such as spermatozoa motility (Boulais et al., 2017), oocyte maturation (Leclerc et al., 2000) and, fertilization (Togo and Morisawa, 1999) in C. gigas. Further studies should investigate the effects of oyster gamete exposure to purified PST, assessing cellular integrity using electronic microscopy, cellular physiology including spermatozoa motility or oocyte maturation, and the consequences on fertilization processes.

In addition to the toxicity of BEC and PST, repeated contacts between oyster gametes and motile thecate dinoflagellates at high concentration $\left(2.5 \times 10^{4}\right.$ cells $\left.\mathrm{mL}^{-1}\right)$ also likely contribute to alter oocytes and spermatozoa cellular integrity, reducing their fertilization capacity. Physical contact with algal cells seems to be an important mechanism involved in the toxicity of HAB species to bivalve gametes and embryos, and has been suggested for Alexandrium species such as A. tamarense, A. taylori and A. affine (Basti et al., 2015; Matsuyama et al., 2001; Yan et al., 2001).

In our experiments, A. minutum cells and their toxins were still present during fertilization since oocytes and spermatozoa were not filtered following exposure to remove algal cells. 311 Therefore, algal concentrations during fertilization ranged from 2.5 to $6.25 \times 10^{3}$ cells $\mathrm{mL}^{-1}$ 312 when performed with previously exposed spermatozoa and from 0.5 to $1.25 \times 10^{3}$ cells $\mathrm{mL}^{-1}$ 313 with previously exposed oocytes. Thus, A. minutum toxins could have directly impaired 314 fertilization process or prevent first cleavage of embryos. Indeed, some Alexandrium strains, 
i.e. A. catenella and A. affine, affected the first and second cleavages of the Japanese pearl oyster P. fucata martensii embryos (Basti et al., 2015).

\section{Conclusion}

This experiment clearly highlights the toxicity of A. minutum on C. gigas gametes and their fertilization capacity and suggests that $A$. minutum blooms could have negative consequences on oyster recruitment. The most striking effects were observed following exposure of oyster gametes to the BEC-producing A. minutum strain, which decreased spermatozoa motility, increased gamete ROS production, and virtually inhibited the subsequent fertilization, thus confirming a PST-independent toxicity of $A$. minutum. Results illustrate that negative effects previously (Castrec et al., 2020), are strain specific and mainly caused by uncharacterized bioactive extracellular compounds, released as exudates and/or associated to algal cell membranes. Further research is necessary to determine the chemical identity of these bioactive compounds produced by A. minutum and the mechanism by which Alexandrium spp. toxins affect bivalve gametes and embryos. These results also participate to illustrate that toxicity vary substantially among clones of the same Alexandrium species (Castrec et al., 2018; Long et al., 2018a; Touzet et al., 2007). As suggested for A. ostenfeldii (Brandenburg et 332 al., 2018), this intraspecific trait variation could be an advantage for development and resilience of A. minutum blooms.

\section{CRediT authorship contribution statement}

335 Justine Castrec: Conceptualization, Methodology, Investigation, Writing - Original Draft, 336 Formal analysis, Visualization. Caroline Fabioux: Conceptualization, Investigation, 337 Supervision, Writing - Review \& Editing. Nelly Le Goïc: Investigation, Resources, Writing 338 Review \& Editing. Myrina Boulais: Conceptualization, Methodology, Investigation, Writing 
- Review \& Editing. Philippe Soudant: Supervision, Writing - Review \& Editing. Hélène

340 Hégaret: Conceptualization, Investigation, Writing - Review \& Editing, Supervision.

\section{Acknowledgments}

342 This work was supported by the French National Research Agency ANR CESA, which 343 founded the ACCUTOX project ANR-13-CESA-0019 (2013-2017). This work was also co-

344 funded by grants from the Regional Council of the Région Bretagne and Brest Métropole. The 345 funding sources had no involvement in study design, collection, analysis and interpretation of 346 the data. The authors gratefully acknowledge all the colleagues who provided a valuable help 347 during the experiment, dissections, discussions and advices: Christophe Lambert, Sylvain 348 Gaillard, and

Kevin Tallec. 


\section{References}

Agarwal, A., Saleh, R.A., Bedaiwy, M.A., 2003. Role of reactive oxygen species in the pathophysiology of human reproduction. Fertil. Steril. 79, 829-843. https://doi.org/10.1016/S0015-0282(02)04948-8

Akcha, F., Spagnol, C., Rouxel, J., 2012. Genotoxicity of diuron and glyphosate in oyster spermatozoa and embryos. Aquat. Toxicol. 106-107, 104-113. https://doi.org/10.1016/j.aquatox.2011.10.018

Anderson, D.M., Alpermann, T.J., Cembella, A.D., Collos, Y., Masseret, E., Montresor, M., 2012. The globally distributed genus Alexandrium: Multifaceted roles in marine ecosystems and impacts on human health. Harmful Algae 14, 10-35. https://doi.org/10.1016/j.hal.2011.10.012

Arzul, G., Seguel, M., Guzman, L., Erard-Le Denn, E., 1999. Comparison of allelopathic properties in three toxic Alexandrium species. J. Exp. Mar. Biol. Ecol. 232, 285-295. https://doi.org/10.1016/S0022-0981(98)00120-8

Banno, K., Oda, T., Nagai, K., Nagai, S., Tanaka, Y., Basti, L., 2018. Deleterious effects of harmful dinoflagellates and raphidophytes on egg viability and spermatozoa swimming velocity in the Japanese pearl oyster Pinctada fucata martensii. J. Shellfish Res. 37, 41-48. https://doi.org/10.2983/035.037.0103

Basti, L., Go, J., Higuchi, K., Nagai, K., Segawa, S., 2011. Effects of the toxic dinoflagellate Heterocapsa circularisquama on larvae of the pearl oyster Pinctada fucata martensii (Dunker, 1873). J. Shellfish Res. 30, 177-186. https://doi.org/10.2983/035.030.0125

Basti, L., Nagai, K., Tanaka, Y., Segawa, S., 2013. Sensitivity of gametes, fertilization, and embryo development of the Japanese pearl oyster, Pinctada fucata martensii, to the harmful dinoflagellate, Heterocapsa circularisquama. Mar. Biol. 160, 211-219. https://doi.org/10.1007/s00227-012-2079-2

Basti, L., Nagai, S., Go, J., Okano, S., Nagai, K., Watanabe, R., Suzuki, T., Tanaka, Y., 2015. Differential inimical effects of Alexandrium spp. and Karenia spp. on cleavage, hatching, and two larval stages of Japanese pearl oyster Pinctada fucata martensii. Harmful Algae 43, 1-12. https://doi.org/10.1016/j.hal.2014.12.004

Bayne, B.L., Ahrens, M., Allen, S.K., D’auriac, M.A., Backeljau, T., Beninger, P., Bohn, R., Boudry, P., Davis, J., Green, T., Guo, X., Hedgecock, D., Ibarra, A., Kingsley-Smith, P., Krause, M., Langdon, C., Lapègue, S., Li, C., Manahan, D., Mann, R., PerezParalle, L., Powell, E.N., Rawson, P.D., Speiser, D., Sanchez, J.-L., Shumway, S., Wang, H., 2017. The proposed dropping of the genus Crassostrea for all Pacific cupped oysters and its replacement by a new genus Magallana: A dissenting view. J. Shellfish Res. 36, 545-547. https://doi.org/10.2983/035.036.0301

Bedaiwy, M.A., Goldberg, J.M., Falcone, T., Singh, M., Nelson, D., Azab, H., Wang, X., Sharma, R., 2002. Relationship between oxidative stress and embryotoxicity of hydrosalpingeal fluid. Hum. Reprod. 17, 601-604. https://doi.org/10.1093/humrep/17.3.601

Bianchi, V.A., Langeloh, H., Tillmann, U., Krock, B., Müller, A., Bickmeyer, U., Abele, D., 2019. Separate and combined effects of neurotoxic and lytic compounds of Alexandrium strains on Mytilus edulis feeding activity and hemocyte function. Fish Shellfish Immunol. 84, 414-422. https://doi.org/10.1016/j.fsi.2018.10.024

Binzer, S.B., Lundgreen, R.B.C., Berge, T., Hansen, P.J., Vismann, B., 2018. The blue mussel Mytilus edulis is vulnerable to the toxic dinoflagellate Karlodinium armiger-Adult filtration is inhibited and several life stages killed. PLOS ONE 13, e0199306. https://doi.org/10.1371/journal.pone.0199306 
Borcier, E., Morvezen, R., Boudry, P., Miner, P., Charrier, G., Laroche, J., Hégaret, H., 2017. Effects of bioactive extracellular compounds and paralytic shellfish toxins produced by Alexandrium minutum on growth and behaviour of juvenile great scallops Pecten Aquat. Toxicol. 184 , $142-154$. https://doi.org/10.1016/j.aquatox.2017.01.009

Boulais, M., Corporeau, C., Huvet, A., Bernard, I., Quéré, C., Quillien, V., Fabioux, C., Suquet, M., 2015a. Assessment of oocyte and trochophore quality in Pacific oyster, Crassostrea gigas. Aquaculture 437, 201-207. https://doi.org/10.1016/j.aquaculture.2014.11.025

Boulais, M., Soudant, P., Le Goïc, N., Quéré, C., Boudry, P., Suquet, M., 2017. ATP content and viability of spermatozoa drive variability of fertilization success in the Pacific oyster (Crassostrea gigas). Aquaculture 479, 114-119. https://doi.org/10.1016/j.aquaculture.2017.05.035

Boulais, M., Soudant, P., Le Goïc, N., Quéré, C., Boudry, P., Suquet, M., 2015b. Involvement of mitochondrial activity and OXPHOS in ATP synthesis during the motility phase of spermatozoa in the Pacific oyster, Crassostrea gigas. Biol. Reprod. biolreprod.115.128538. https://doi.org/10.1095/biolreprod.115.128538

Boulais, M., Suquet, M., Arsenault-Pernet, E.J., Malo, F., Queau, I., Pignet, P., Ratiskol, D., Le Grand, J., Huber, M., Cosson, J., 2018. pH controls spermatozoa motility in the Pacific oyster (Crassostrea gigas). Biol. Open 7, bio031427. https://doi.org/10.1242/bio.031427

Brandenburg, K.M., Wohlrab, S., John, U., Kremp, A., Jerney, J., Krock, B., Van de Waal, D.B., 2018. Intraspecific trait variation and trade-offs within and across populations of a toxic dinoflagellate. Ecol. Lett. 0. https://doi.org/10.1111/ele.13138

Bricelj, V.M., MacQuarrie, S.P., 2007. Effects of brown tide (Aureococcus anophagefferens) on hard clam Mercenaria mercenaria larvae and implications for benthic recruitment. Mar. Ecol. Prog. Ser. 331, 147-159. https://doi.org/10.3354/meps331147

Bricelj, V.M., Shumway, S.E., 1998. Paralytic shellfish toxins in bivalve molluscs: Occurrence, transfer kinetics, and biotransformation. Rev. Fish. Sci. 6, 315-383. https://doi.org/10.1080/10641269891314294

Castrec, J., Hégaret, H., Alunno-Bruscia, M., Picard, M., Soudant, P., Petton, B., Boulais, M., Suquet, M., Quéau, I., Ratiskol, D., Foulon, V., Le Goïc, N., Fabioux, C., 2019. The dinoflagellate Alexandrium minutum affects development of the oyster Crassostrea gigas, through parental or direct exposure. Environ. Pollut. 246, 827-836. https://doi.org/10.1016/j.envpol.2018.11.084

Castrec, J., Hégaret, H., Huber, M., Le Grand, J., Huvet, A., Tallec, K., Boulais, M., Soudant, P., Fabioux, C., 2020. The toxic dinoflagellate Alexandrium minutum impairs the performance of oyster embryos and larvae. Harmful Algae 92, 101744. https://doi.org/10.1016/j.hal.2020.101744

Castrec, J., Soudant, P., Payton, L., Tran, D., Miner, P., Lambert, C., Le Goïc, N., Huvet, A., Quillien, V., Boullot, F., Amzil, Z., Hégaret, H., Fabioux, C., 2018. Bioactive extracellular compounds produced by the dinoflagellate Alexandrium minutum are highly detrimental for oysters. Aquat. Toxicol. 199, 188-198. https://doi.org/10.1016/j.aquatox.2018.03.034

Chapelle, A., Le Gac, M., Labry, C., Siano, R., Quere, J., Caradec, F., Le Bec, C., Nezan, E., Doner, A., Gouriou, J., 2015. The Bay of Brest (France), a new risky site for toxic Alexandrium minutum blooms and PSP shellfish contamination. Harmful Algae News $51,4-5$. 
De Rijcke, M., Van Acker, E., Nevejan, N., De Schamphelaere, K.A.C., Janssen, C.R., 2016. Toxic dinoflagellates and Vibrio spp. act independently in bivalve larvae. Fish Shellfish Immunol. 57, 236-242. https://doi.org/10.1016/j.fsi.2016.08.027

De Rijcke, M., Vandegehuchte, M.B., Vanden Bussche, J., Nevejan, N., Vanhaecke, L., De Schamphelaere, K.A.C., Janssen, C.R., 2015. Common European harmful algal blooms affect the viability and innate immune responses of Mytilus edulis larvae. Fish Shellfish Immunol. 47, 175-181. https://doi.org/10.1016/j.fsi.2015.09.003

Fabioux, C., Sulistiyani, Y., Haberkorn, H., Hégaret, H., Amzil, Z., Soudant, P., 2015. Exposure to toxic Alexandrium minutum activates the detoxifying and antioxidant systems in gills of the oyster Crassostrea gigas. Harmful Algae 48, 55-62. https://doi.org/10.1016/j.hal.2015.07.003

Fitzpatrick, J.L., Nadella, S., Bucking, C., Balshine, S., Wood, C.M., 2008. The relative sensitivity of sperm, eggs and embryos to copper in the blue mussel (Mytilus trossulus). Comp. Biochem. Physiol. Part C Toxicol. Pharmacol. 147, 441-449. https://doi.org/10.1016/j.cbpc.2008.01.012

Ford, S.E., Bricelj, V.M., Lambert, C., Paillard, C., 2008. Deleterious effects of a nonPST bioactive compound(s) from Alexandrium tamarense on bivalve hemocytes. Mar. Biol. 154, 241-253. https://doi.org/10.1007/s00227-008-0917-z

Gaillard, S., Le Goïc, N., Malo, F., Boulais, M., Fabioux, C., Zaccagnini, L., Carpentier, L., Sibat, M., Réveillon, D., Séchet, V., Hess, P., Hégaret, H., 2020. Cultures of Dinophysis sacculus, D. acuminata and pectenotoxin 2 affect gametes and fertilization success of the Pacific oyster, Crassostrea gigas. Environ. Pollut. 114840. https://doi.org/10.1016/j.envpol.2020.114840

Garcés, E., Bravo, I., Vila, M., Figueroa, R.I., Masó, M., Sampedro, N., 2004. Relationship between vegetative cells and cyst production during Alexandrium minutum bloom in Arenys de Mar harbour (NW Mediterranean). J. Plankton Res. 26, 637-645. https://doi.org/10.1093/plankt/fbh065

Guallar, C., Bacher, C., Chapelle, A., 2017. Global and local factors driving the phenology of Alexandrium minutum (Halim) blooms and its toxicity. Harmful Algae 67, 44-60. https://doi.org/10.1016/j.hal.2017.05.005

Guillard, R.R.L., Hargraves, P.E., 1993. Stichochrysis immobilis is a diatom, not a chrysophyte. Phycologia 32, 234-236. https://doi.org/10.2216/i0031-8884-32-3-234.1

Haberkorn, H., Lambert, C., Le Goïc, N., Moal, J., Suquet, M., Guéguen, M., Sunila, I., Soudant, P., 2010. Effects of Alexandrium minutum exposure on nutrition-related processes and reproductive output in oysters Crassostrea gigas. Harmful Algae 9, 427-439. https://doi.org/10.1016/j.hal.2010.01.003

Havenhand, J.N., Buttler, F.-R., Thorndyke, M.C., Williamson, J.E., 2008. Near-future levels of ocean acidification reduce fertilization success in a sea urchin. Curr. Biol. 18, R651-R652. https://doi.org/10.1016/j.cub.2008.06.015

Hu, Y., Betzendahl, I., Cortvrindt, R., Smitz, J., Eichenlaub-Ritter, U., 2001. Effects of low $\mathrm{O} 2$ and ageing on spindles and chromosomes in mouse oocytes from pre-antral follicle culture. Hum. Reprod. 16, 737-748. https://doi.org/10.1093/humrep/16.4.737

Labib, W., Halim, Y., 1995. Diel vertical migration and toxicity of Alexandrium minutum Halim red tide, in Alexandria, Egypt. Mar. Life 5, 11-17.

Le Goïc, N., Hégaret, H., Boulais, M., Béguel, J.-P., Lambert, C., Fabioux, C., Soudant, P., 2014. Flow cytometric assessment of morphology, viability, and production of reactive oxygen species of Crassostrea gigas oocytes: Application to toxic dinoflagellate (Alexandrium minutum) exposure. Cytom. Part J. Int. Soc. Anal. Cytol. 85, 1049-1056. https://doi.org/10.1002/cyto.a.22577 
Le Goïc, N., Hégaret, H., Fabioux, C., Miner, P., Suquet, M., Lambert, C., Soudant, P., 2013. Impact of the toxic dinoflagellate Alexandrium catenella on Pacific oyster reproductive output: Application of flow cytometry assays on spermatozoa. Aquat. Living Resour. 26, 8. https://doi.org/10.1051/alr/2013047

Leclerc, C., Guerrier, P., Moreau, M., 2000. Role of dihydropyridine-sensitive calcium channels in meiosis and fertilization in the bivalve molluscs Ruditapes philippinarum and Crassostrea gigas. Biol. Cell 92, 285-299. https://doi.org/10.1016/S02484900(00)01069-8

Lefebvre, K.A., Bill, B.D., Erickson, A., Baugh, K.A., O’Rourke, L., Costa, P.R., Nance, S., Trainer, V.L., 2008. Characterization of intracellular and extracellular saxitoxin levels in both field and cultured Alexandrium spp. samples from Sequim Bay, Washington. Mar. Drugs 6, 103-116. https://doi.org/10.3390/md20080006

Lelong, A., Haberkorn, H., Le Goïc, N., Hégaret, H., Soudant, P., 2011. A new insight into allelopathic effects of Alexandrium minutum on photosynthesis and respiration of the diatom Chaetoceros neogracile revealed by photosynthetic-performance analysis and flow cytometry. Microb. Ecol. 62, 919-930. https://doi.org/10.1007/s00248-011-98895

Llewellyn, L.E., 2006. Saxitoxin, a toxic marine natural product that targets a multitude of receptors. Nat. Prod. Rep. 23, 200-222. https://doi.org/10.1039/B501296C

Long, M., Tallec, K., Soudant, P., Lambert, C., Le Grand, F., Sarthou, G., Jolley, D., Hégaret, H., 2018a. A rapid quantitative fluorescence-based bioassay to study allelochemical interactions from Alexandrium minutum. Environ. Pollut. 242, 1598-1605. https://doi.org/10.1016/j.envpol.2018.07.119

Long, M., Tallec, K., Soudant, P., Le Grand, F., Donval, A., Lambert, C., Sarthou, G., Jolley, D.F., Hégaret, H., 2018b. Allelochemicals from Alexandrium minutum induce rapid inhibition of metabolism and modify the membranes from Chaetoceros muelleri. Algal Res. 35, 508-518. https://doi.org/10.1016/j.algal.2018.09.023

Mai, H., Morin, B., Pardon, P., Gonzalez, P., Budzinski, H., Cachot, J., 2013. Environmental concentrations of irgarol, diuron and S-metolachlor induce deleterious effects on gametes and embryos of the Pacific oyster, Crassostrea gigas. Mar. Environ. Res. 89, 1-8. https://doi.org/10.1016/j.marenvres.2013.04.003

Manduzio, H., Rocher, B., Durand, F., Galap, C., Leboulenger, F., 2005. The point about oxidative stress in molluscs. Invertebr. Surviv. J. 2, 91-104.

Mardones, J.I., Dorantes-Aranda, J.J., Nichols, P.D., Hallegraeff, G.M., 2015. Fish gill damage by the dinoflagellate Alexandrium catenella from Chilean fjords: Synergistic action of ROS and PUFA. Harmful Algae 49, 40-49. https://doi.org/10.1016/j.hal.2015.09.001

Marie, D., Brussaard, C.P.D., Thyrhaug, R., Bratbak, G., Vaulot, D., 1999. Enumeration of marine viruses in culture and natural samples by flow cytometry. Appl. Environ. Microbiol. 65, 45-52.

Marshall, D.J., Styan, C.A., Keough, M.J., 2002. Sperm environment affects offspring quality in broadcast spawning marine invertebrates. Ecol. Lett. 5, 173-176. https://doi.org/10.1046/j.1461-0248.2002.00257.x

Martín-Romero, F.J., Miguel-Lasobras, E.M., Domínguez-Arroyo, J.A., González-Carrera, E., Álvarez, I.S., 2008. Contribution of culture media to oxidative stress and its effect on human oocytes. Reprod. Biomed. Online 17, 652-661. https://doi.org/10.1016/S14726483(10)60312-4

Matsuyama, Y., Usuki, H., Uchida, T., Kotani, Y., 2001. Effects of harmful algae on the early planktonic larvae of the oyster, Crassostrea gigas. G.M. Hallegraeff, S.I. Blackburn, 
C.J. Bolch, R.J. Lewis (Eds.), Proceedings of the Ninth International Conference on Harmful Algal Blooms, IOC of UNESCO, Paris (2001), pp. 411-414.

$\mathrm{Mu}, \mathrm{C} ., \mathrm{Li}, \mathrm{Q} ., 2013$. Effects of the dinoflagellate Alexandrium catenella on the early development of the Pacific oyster Crassostrea gigas. J. Shellfish Res. 32, 689-694. https://doi.org/10.2983/035.032.0310

Nice, H.E., 2005. Sperm motility in the Pacific oyster (Crassostrea gigas) is affected by nonylphenol. Mar. Pollut. Bull. 50, 1668-1674. https://doi.org/10.1016/j.marpolbul.2005.07.006

Petton, B., Boudry, P., Alunno-Bruscia, M., Pernet, F., 2015. Factors influencing diseaseinduced mortality of Pacific oysters Crassostrea gigas. Aquac. Environ. Interact. 6, 205-222. https://doi.org/10.3354/aei00125

Pitcher, G.C., Cembella, A.D., Joyce, L.B., Larsen, J., Probyn, T.A., Ruiz Sebastián, C., 2007. The dinoflagellate Alexandrium minutum in Cape Town harbour (South Africa): Bloom characteristics, phylogenetic analysis and toxin composition. Harmful Algae 6, 823-836. https://doi.org/10.1016/j.hal.2007.04.008

Pousse, É., Flye-Sainte-Marie, J., Alunno-Bruscia, M., Hégaret, H., Jean, F., 2018. Sources of paralytic shellfish toxin accumulation variability in the Pacific oyster Crassostrea gigas. Toxicon 144, 14-22. https://doi.org/10.1016/j.toxicon.2017.12.050

Pouvreau, S., Daniele, M., Auby, I., Lagarde, F., Le Gall, P., Cochet, H., 2016. Velyger database: the oyster larvae monitoring French project. SEANOE Doi 10, 41888.

Rolton, A., Soudant, P., Vignier, J., Pierce, R., Henry, M., Shumway, S.E., Bricelj, V.M., Volety, A.K., 2015. Susceptibility of gametes and embryos of the eastern oyster, Crassostrea virginica, to Karenia brevis and its toxins. Toxicon 99, 6-15. https://doi.org/10.1016/j.toxicon.2015.03.002

Rolton, A., Vignier, J., Soudant, P., Shumway, S.E., Bricelj, V.M., Volety, A.K., 2014. Effects of the red tide dinoflagellate, Karenia brevis, on early development of the eastern oyster Crassostrea virginica and northern quahog Mercenaria mercenaria. Aquat. Toxicol. 155, 199-206. https://doi.org/10.1016/j.aquatox.2014.06.023

Rolton, A., Vignier, J., Volety, A., Shumway, S., Bricelj, V.M., Soudant, P., 2018. Impacts of exposure to the toxic dinoflagellate Karenia brevis on reproduction of the northern quahog, Mercenaria mercenaria. Aquat. Toxicol. 202, 153-162. https://doi.org/10.1016/j.aquatox.2018.07.007

Sanocka, D., Kurpisz, M., 2004. Reactive oxygen species and sperm cells. Reprod. Biol. Endocrinol. 2, 12. https://doi.org/10.1186/1477-7827-2-12

Styan, C.A., 1998. Polyspermy, egg size, and the fertilization kinetics of free- spawning marine invertebrates. Am. Nat. 152, 290-297. https://doi.org/10.1086/286168

Takahashi, T., Takahashi, E., Igarashi, H., Tezuka, N., Kurachi, H., 2003. Impact of oxidative stress in aged mouse oocytes on calcium oscillations at fertilization. Mol. Reprod. Dev. 66, 143-152. https://doi.org/10.1002/mrd.10341

Tang, Y.Z., Gobler, C.J., 2012. Lethal effects of Northwest Atlantic Ocean isolates of the dinoflagellate, Scrippsiella trochoidea, on Eastern oyster (Crassostrea virginica) and Northern quahog (Mercenaria mercenaria) larvae. Mar. Biol. 159, 199-210. https://doi.org/10.1007/s00227-011-1800-x

Togo, T., Morisawa, M., 1999. Mechanisms for blocking polyspermy in oocytes of the oyster Crassostrea gigas. J. Exp. Zool. 283, 307-314. https://doi.org/10.1002/(SICI)1097010X(19990215)283:3<307::AID-JEZ8>3.0.CO;2-N

Touzet, N., Franco, J.M., Raine, R., 2007. Characterization of nontoxic and toxin-producing strains of Alexandrium minutum (Dinophyceae) in Irish coastal waters. Appl. Environ. Microbiol. 73, 3333-3342. https://doi.org/10.1128/AEM.02161-06 
Vignier, J., Donaghy, L., Soudant, P., Chu, F.L.E., Morris, J.M., Carney, M.W., Lay, C., Krasnec, M., Robert, R., Volety, A.K., 2015. Impacts of Deepwater Horizon oil and associated dispersant on early development of the Eastern oyster Crassostrea virginica. Mar. Pollut. Bull. 100, 426-437. https://doi.org/10.1016/j.marpolbul.2015.08.011

Vignier, J., Volety, A.K., Rolton, A., Le Goïc, N., Chu, F.-L.E., Robert, R., Soudant, P., 2017. Sensitivity of eastern oyster (Crassostrea virginica) spermatozoa and oocytes to dispersed oil: Cellular responses and impacts on fertilization and embryogenesis. Environ. Pollut. 225, 270-282. https://doi.org/10.1016/j.envpol.2016.11.052

Yan, T., Zhou, M., Fu, M., Wang, Y., Yu, R., Li, J., 2001. Inhibition of egg hatching success and larvae survival of the scallop, Chlamys farreri, associated with exposure to cells and cell fragments of the dinoflagellate Alexandrium tamarense. Toxicon 39, 12391244. https://doi.org/10.1016/S0041-0101(01)00080-0 


\section{Highlights}

- Oyster spermatozoa and oocytes were exposed in vitro to Alexandrium minutum strains.

- Viability and fertilization capacity of gametes were drastically reduced.

- The toxicity of Alexandrium minutum upon oyster gametes is strain-specific.

- A non-PST-producing strain increased reactive oxygen species production in oocytes.

- This strain also decreased spermatozoa motility and gamete fertilization. 


\section{Declaration of interests}

$\bigotimes$ The authors declare that they have no known competing financial interests or personal relationships that could have appeared to influence the work reported in this paper.

$\square$ The authors declare the following financial interests/personal relationships which may be considered as potential competing interests:

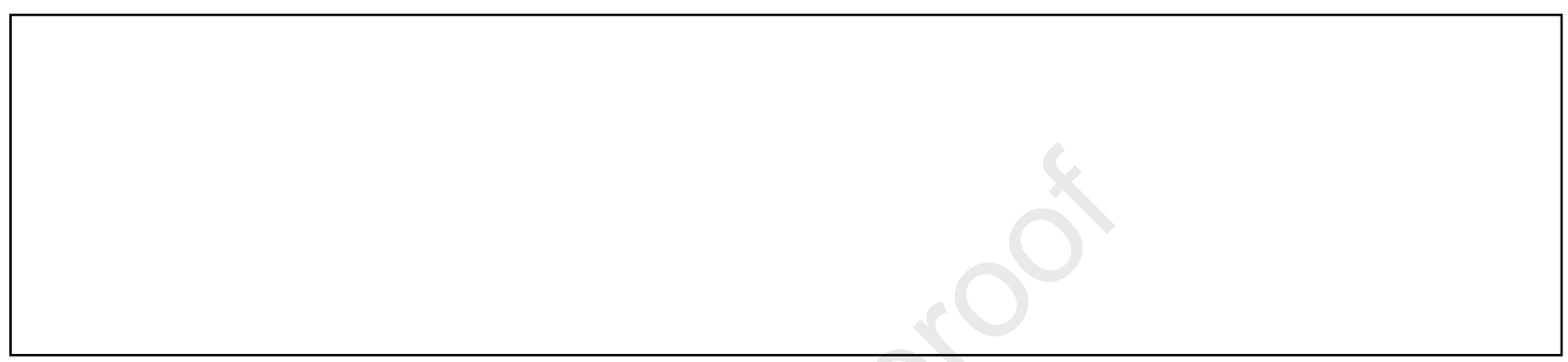

